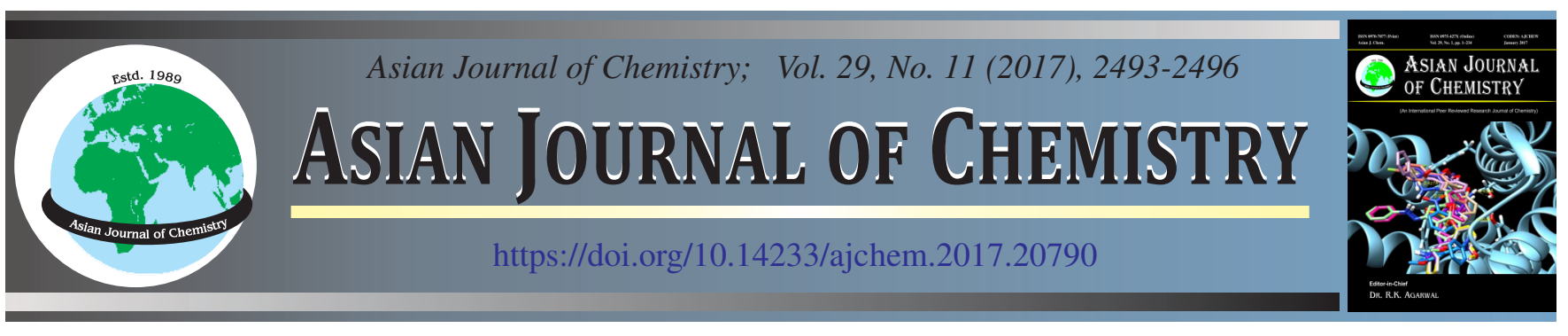

\title{
Determination of Nutritional Composition of Some Selected Fishes from Hel River of North-East India
}

\author{
ArJina Parbin SARkar ${ }^{1}$, SAnJay Basumatary ${ }^{2, *}$ and SAndeer Das ${ }^{1}$
}

${ }^{1}$ Department of Biotechnology, Bodoland University, Kokrajhar-783 370, India

${ }^{2}$ Department of Chemistry, Bodoland University, Kokrajhar-783 370, India

*Corresponding author: E-mail: waytosanjay12@gmail.com

Received: 19 May 2017;

Accepted: 28 July 2017;

Published online: 29 September 2017;

AJC-18579

In this study, proximate composition and mineral contents of ten fish species viz. Barilius bendelisis, Chagunius chagunio, Garra gotyla,
Labeo pangusia, Neolissochilus hexagonolepis, Raiamas bola, Tor putitora, Cyprinion semiplotum, Barilius barna and Psilorhynchus
nudithoracicus from Hel river of North-East India were investigated and all the results were presented per $100 \mathrm{~g}$ of dry weight basis. The
moisture content was found in the range of $5.44 \pm 2.20 \mathrm{~g}$ to $8.87 \pm 1.46 \mathrm{~g}$. Ash content varied from $1.28 \pm 0.017 \mathrm{~g}$ in $B$. barna to $3.20 \pm$
$0.012 \mathrm{~g}$ in $N$. hexagonolepis. The crude protein content was found highest in $G$. gotyla $(29.33 \pm 0.249 \mathrm{~g})$ and the lowest in $R$. bola $(21.91$
$\pm 0.012 \mathrm{~g})$, and crude fat was found to be lowest in $B$. barna $(13.51 \pm 0.010 \mathrm{~g})$ and highest being in $C$. semiplotum $(29.85 \pm 0.010 \mathrm{~g})$. Total
carbohydrate was found in the range of $38.55 \pm 0.21 \mathrm{~g}$ to $53.92 \pm 0.57 \mathrm{~g}$, and the lowest nutritive value was obtained in $C$. chagunio
$(426.95 \pm 4.53 \mathrm{kcal} / 100 \mathrm{~g})$ and the highest nutritive value being in $C$. semiplotum $(521.38 \pm 9.23 \mathrm{kcal} / 100 \mathrm{~g})$. The highest level of iron was
detected in $C$. chagunio $(21.89 \pm 0.029 \mathrm{mg})$ and lowest in $B$. barna $(5.56 \pm 0.071 \mathrm{mg})$. The highest amount of copper was observed in $N$.
hexagonolepis $(2.91 \pm 0.029 \mathrm{mg})$ and the lowest in $R$. bola $(0.523 \pm 0.034 \mathrm{mg})$. The magnesium, calcium and zinc levels varied from 0.14
\pm 0.006 to $0.31 \pm 0.017 \mathrm{mg}, 0.30 \pm 0.012$ to $0.64 \pm 0.020 \mathrm{mg}$ and $1.06 \pm 0.044$ to $4.51 \pm 0.029 \mathrm{mg}$, respectively. It can be concluded that
the fish species selected for this study could be good sources of proteins, fats, minerals and high nutritive value for human consumption.

Keywords: Proximate composition, Minerals, Fish, Hel river.

\section{INTRODUCTION}

Fish is one of the most potential sources of nutrient containing proteins, fats, carbohydrates, vitamins and minerals required for healthy human body maintenance [1]. All over the world, consumption of fish is increasing among the healthconscious populace. Fish is considered as one of the most important sources of high quality animal protein in the diet consisting of essential amino acids for growth and maintenance of human body, and has a crucial role in food security and mitigation of poverty in both rural and urban areas [2]. In comparison to other protein sources like goat and chicken meat, fish is safer, healthier and is also known to be an excellent source of easily digestible animal protein [3]. Fats are important sources of energy, fat-soluble vitamins and unsaturated fatty acids [4]. Recently, there is increasing interest of fish consumption worldwide because of their high content of polyunsaturated fatty acids, especially the $\omega-3$ fatty acids viz. eicosapentaenoic acid (C20:5) and docosahexaenoic acid (C22:6) [5]. These two fatty acids are known as essential fatty acids because they must be obtained from the diet as human body cannot synthesize them. Furthermore, fish consumption has been associated with several health benefits as the long chain polyunsaturated fatty acids have gained increasing attention because of prevention of coronary artery disease, improvement of retina and brain development, reduced incidence of breast cancer, rheumatoid arthritis, multiple scelerosis, asthma, psoriasis, inflammatory bowel disease and regulation of prostaglandin synthesis [6,7].

Minerals are essential nutrients and components of many enzymes and metabolism which contribute to the growth of fish [8]. Fish mineral and metal contents vary based on the surrounding environmental conditions and fish species. All living organisms require minerals at moderate levels for many biochemical activities and their deficiency induces a lot of malfunctioning causing reduced productivity and several diseases [9]. When the metabolic demand or requirement levels of minerals exceed, they tend to become accumulated in tissues of organisms which can only metabolize these substances to lesser extents because most of the heavy metals are nonbiodegradable [3]. The study of nutritional composition of fish species is important biologically as many of these components 
take part in some metabolic processes and is known to be essential to all the living things and serves as potential sources of energy for human beings [10,11].

North-East (NE) India comprising of eight states viz. Assam, Arunachal Pradesh, Manipur, Meghalaya, Mizoram, Nagaland, Tripura and Sikkim is famous for its multi-ethnicity and rich biological resources. The region has very friendly climatic conditions, diversity of plants many of which have their own biological values and the rural and tribal people of the region mostly depend on biological assets for their food, shelter, medicare and other cultural purposes [12-15]. The Hel river stream of western Assam originates from Bhutan. This river is also known as Gangia river at Dotma, Kokrajhar and it meets the Brahmaputra river near Bagribari. Some researchers have studied biochemical compositions of fish from North East India and most of the reports are mainly from Tripura and Manipur. Debnath et al. [16] reported protein and mineral compositions of some local fishes of Tripura, India. Hei and Sarojnalini [17] reported proximate composition, macro and micro-mineral elements of some smoke-dried hill stream fishes from Manipur, India. Devi et al. [18] reported protein contents of chocolate mahseer ( $N$. hexagonolepis) of Iyei river of Manipur. Ullah et al. [19] reported biochemical quality of ten selected dried fish species of North East India. Romharsha et al. [20] also reported proximate composition and amino acid profile of some hill-stream fishes of Manipur. However, there is no report in the literature so far on the Hel river fishes of Assam of North-East India. The present study was undertaken to investigate the nutritional composition of ten fish species from Hel river of North-East India.

\section{EXPERIMENTAL}

Sample collection, identification and preparation: A total of ten fish species from Hel river were collected from Serfanguri, Kokrajhar, Assam of North-East India from fishermen during the time of June to December, 2015. The species for identification were taken into specimen jar containing preservative ( $4 \%$ formalin) and identified with the help of Zoological Survey of India, Shillong, Meghalaya (No. F. 4-2/2015-16/Tech./555, 4th August, 2015 and No. F. 4-2/ 2015-16/Tech./87, 5th February, 2016). For determination of proximate and mineral compositions, the fishes were washed with running tap water, dried at $55^{\circ} \mathrm{C}$ in a hot air oven for two days, boneless muscles were collected, mashed to fine powder with a grinder, taken in air tight plastic container and then stored at $-20^{\circ} \mathrm{C}$ in a deep freezer till further analyses. All the solvents and chemicals used in this study were of analytical grade and used without further purification.

Determination of moisture content: The moisture content was determined following AOAC method [21]. Dried sample ( $3 \mathrm{~g}$ ) was heated in a hot air oven at $105^{\circ} \mathrm{C}$ for $3 \mathrm{~h}$, cooled in desiccator, weighted and the moisture content calculated.

$$
\text { Moisture }(\%)=\frac{(\text { Weight of sample }- \text { Dry weight })}{\text { Weight of the sample taken }} \times 100
$$

Determination of total solids: The total solid was calculated by subtracting percentage of moisture from the hundred [22].
Total solid = $100-$ Moisture $(\%)$

Determination of ash content: The ash content was determined by the AOAC method [21]. Briefly, empty silica crucible was heated first in a muffle furnace, cooled in a desiccator and the initial weight was taken till constant value. Sample (5 g) was heated in a muffle furnace at $550{ }^{\circ} \mathrm{C}$ for $6 \mathrm{~h}$, cooled in desiccator, weight of the ash was taken and ash content calculated.

$$
\text { Ash }(\%)=\frac{\text { Weight of ash }}{\text { Weight of the sample }} \times 100
$$

Determination of crude protein: Crude protein was estimated using Kjeldhal method (Buchi Kjelflex K-360) following AOAC procedure [21]. $0.5 \mathrm{~g}$ of the sample was taken and the nitrogen was estimated first. Total protein was calculated by multiplying the evaluated nitrogen by a protein conversion factor of 6.25 .

Protein $(\%)=$ Nitrogen $(\%) \times 6.25$ (conversion factor)

Determination of crude fat: The crude fat content was calculated following AOAC method [21]. Sample (3 g) was extracted with petroleum ether using Soxhlet apparatus for about $14 \mathrm{~h}$. The extracted fat was dried in a rotary evaporator and the weight was noted.

$$
\text { Crude fat }(\%)=\frac{\text { Weight of fat }}{\text { Weight of the sample }} \times 100
$$

Determination of total carbohydrate: The carbohydrate content was calculated by the difference method [22] according to the following formula:

Carbohydrate $(\%)=100-[$ Moisture $(\%)+$ Ash $(\%)+$ Crude protein $(\%)+$ Crude fat $(\%)]$

Nutritive value: Nutritive value or calorific value in $\mathrm{kcal} /$ $100 \mathrm{~g}$ was calculated with the help of the following equation [23]:

$$
\begin{gathered}
\text { Calorific value }(\mathrm{kcal} / 100 \mathrm{~g})=4 \times \text { Protein }(\%)+ \\
9 \times \text { Fat }(\%)+4 \times \text { Carbohydrate }(\%)
\end{gathered}
$$

Determination of minerals: Minerals were determined using Graphite Furnace-Atomic Absorption Spectrometer (GFAAS, Analytik Jena Vario-6) at Sophisticated Analytical Instrumentation Facility (SAIF), North Eastern Hill University, Shillong, India. Samples were digested using concentrated $\mathrm{HNO}_{3}$ and the results obtained were converted to $\mathrm{mg} / 100 \mathrm{~g}$ of dried sample.

Statistical analysis: The experimental results were expressed as mean of three replicates \pm standard deviation. Relative significant differences among the means were determined by one-way ANOVA $t$-test at $p<0.05$. Statistical calculations were carried out at Microsoft Excel and OriginPro 8.5 software (OriginLab Corporation, MA 01060 USA).

\section{RESULTS AND DISCUSSION}

The ten fish species selected for this study, their local name, family and IUCN status are presented in Table-1. A total of six fish species of these are least concerned (LC), two are near threatened (NT), one endangered (EN) and one vulnerable (VU). Table-2 presents the results of proximate analysis per $100 \mathrm{~g}$ of dry weight and it shows that all the ten 
fish species have variable values of proximate composition. The moisture content ranged from $5.44 \pm 2.20 \mathrm{~g}$ to $8.87 \pm$ $1.46 \mathrm{~g}$, lowest being in $P$. nudithoracicus and highest in $L$. pangusia. The moisture content of fresh fish species was found varying from $73.16 \pm 0.28 \mathrm{~g}$ in T. putitora to $82.58 \pm 0.39 \mathrm{~g}$ in L. pangusia. Ash content was found ranging from $1.28 \pm 0.017$ $\mathrm{g}$ in B. barna (lowest) to $3.20 \pm 0.012 \mathrm{~g}$ in $N$. hexagonolepis (highest) and found more or less similar to the values of some cold-water fishes of upland Himalaya reported by Sarma et al. [2]. The total solid of fish species varied from $91.13 \pm 1.46$ $\mathrm{g}$ (L. pangusia) to $94.56 \pm 2.20 \mathrm{~g}$ ( $P$. nudithoracicus). In this investigation, the crude protein contents ranged from $21.91 \pm$ $0.012 \mathrm{~g}(R$. bola $)$ to $29.33 \pm 0.249 \mathrm{~g}(G$. gotyla $)$ and the crude fat ranged from $13.51 \pm 0.009 \mathrm{~g}$ in B. barna to $29.85 \pm 0.008 \mathrm{~g}$ in C. semiplotum. In comparison to this study, Hei and Sarojnalini [17] reported higher crude protein content and less fat content in some smoke-dried hill stream fishes from Manipur, India. Higher protein content of some local fishes of Tripura, India ranging from $39.37 \%$ to $75.43 \%$ was also reported by Debnath et al. [19]. Sarma et al. [2] also reported the protein content of some cold-water fishes of upland Himalaya that ranged from $16 \pm 0.3 \%$ to $20 \pm 0.5 \%$ and fat content varied from $1.5 \pm$ $0.1 \%$ to $7.6 \pm 0.5 \%$ based on wet weight basis. However, high crude fat content of fish species from Hel river was found in the present investigation. Proteins and fats are the main nutrients in fishes and their levels assist to express the nutritional status of a particular organism [24]. Fats are required in diets to absorb fat-soluble vitamins viz., vitamin A, D, E and K from food and for regulating body cholesterol metabolism [25]. The total carbohydrate content was found varying from $38.55 \pm 0.21 \mathrm{~g}$ (C. semiplotum) to $53.92 \pm 0.57 \mathrm{~g}(R$. bola $)$. The nutritive or energy value of fish species was found maximum in $C$. semiplotum $(521.38 \pm 9.23 \mathrm{kcal} / 100 \mathrm{~g})$ followed by $P$. nudithoracicus $(503.52 \pm 9.06 \mathrm{kcal} / 100 \mathrm{~g})$ and B. bendelisis (499.56 \pm 1.83 $\mathrm{kcal} / 100 \mathrm{~g}$ ) and the lowest value was observed in $C$. chagunio $(426.95 \pm 4.53 \mathrm{kcal} / 100 \mathrm{~g})$. The key nutrients of life are proteins, fats and carbohydrates. The food rich in proteins, fats and carbohydrates supplies more energy which is responsible for doing various activities in our daily life [12,26].

The mineral contents of ten fish species per $100 \mathrm{~g}$ of dry weight are presented in Table-3. The highest level of iron was detected in C. chagunio $(21.89 \pm 0.029 \mathrm{mg})$ and the lowest in B. barna $(5.56 \pm 0.071 \mathrm{mg})$. The iron content of ten coldwater fish species from North-Eastern Himalayan region reported by Sarma et al. [2] varied from $1.4 \pm 0.2$ to $21.0 \pm 0.7 \mathrm{mg} / 100$ g. Hei and Sarojnalini [17] reported the levels of iron in some

TABLE-1

FISH SPECIES FROM HEL RIVER SELECTED FOR PRESENT STUDY

\begin{tabular}{lccc}
\hline \multicolumn{1}{c}{ Scientific name } & Local name (Assamese) & Family & IUCN Status [2015] \\
\hline Barilius bendelisis (Hamilton, 1822) & Elang & Cyprinidae & LC \\
Chagunius chagunio (Hamilton, 1822) & Pitkata & Cyprinidae & LC \\
Garra gotyla (Gray, 1832) & Siltoka & Cyprinidae & LC \\
Labeo pangusia (Hamilton, 1822) & Ghoira & Cyprinidae & NT \\
Neolissochilus hexagonolepis (McClelland, 1839) & Vuluk & Cyprinidae & CT \\
Raiamas bola (Hamilton, 1822) & Chela & LC \\
Tor putitora (Hamilton, 1822) & Jongator & Cyprinidae & EN \\
Cyprinion semiplotum (McClelland, 1839) & Bhutia puthi & Cyprinidae & VU \\
Barilius barna (Hamilton, 1822) & Kabri peri & Cyprinidae & LC \\
Psilorhynchus nudithoracicus (Tilak and Husain, 1980) & Gol & Psilorhynchidae & LC \\
\hline LC, Least concerned; NT, Near threatened; EN, Endangered; VU, Vulnerable. & &
\end{tabular}

TABLE-2

PROXIMATE ANALYSIS OF TEN FISH SPECIES PER $100 \mathrm{~g}$ OF DRY WEIGHT

\begin{tabular}{|c|c|c|c|c|c|c|c|}
\hline Fish species & Moisture (g) & Ash (g) & Total solid (g) & $\begin{array}{c}\text { Crude } \\
\text { protein }(\mathrm{g})\end{array}$ & $\begin{array}{l}\text { Crude } \\
\text { fat }(g)\end{array}$ & $\begin{array}{l}\text { Carbohydrate } \\
\text { (g) }\end{array}$ & $\begin{array}{c}\text { Nutritive } \\
\text { value (kcal) }\end{array}$ \\
\hline B. bendelisis & $\begin{array}{c}7.40 \pm 0.47^{\mathrm{a}} \\
79.76 \pm 0.43^{*}\end{array}$ & $1.51 \pm 0.042^{\mathrm{a}}$ & $92.60 \pm 0.47^{\mathrm{a}}$ & $22.48 \pm 0.005^{\mathrm{a}}$ & $27.04 \pm 0.016^{\mathrm{a}}$ & $41.57 \pm 0.42^{\mathrm{a}}$ & $499.56 \pm 1.83^{\mathrm{a}}$ \\
\hline C. chagunio & $\begin{array}{c}8.74 \pm 1.13^{\mathrm{b}} \\
74.38 \pm 0.83^{*}\end{array}$ & $2.86 \pm 0.032^{\mathrm{b}}$ & $91.26 \pm 1.13 b$ & $22.47 \pm 0.008^{\mathrm{a}}$ & $14.67 \pm 0.012^{\mathrm{b}}$ & $51.27 \pm 1.15^{\mathrm{b}}$ & $426.95 \pm 4.53^{b}$ \\
\hline G. gotyla & $\begin{array}{c}6.59 \pm 0.55^{\mathrm{c}} \\
82.04 \pm 2.02^{*}\end{array}$ & $2.18 \pm 0.074^{c}$ & $93.41 \pm 0.55^{c}$ & $29.33 \pm 0.249^{b}$ & $17.93 \pm 0.012^{c}$ & $43.97 \pm 0.34^{c}$ & $454.55 \pm 2.44^{\mathrm{c}}$ \\
\hline L. pangusia & $\begin{array}{c}8.87 \pm 1.46^{\mathrm{b}} \\
82.58 \pm 0.39^{*}\end{array}$ & $2.51 \pm 0.012^{\mathrm{c}, \mathrm{d}}$ & $91.13 \pm 1.46^{\mathrm{b}}$ & $23.35 \pm 0.033^{c}$ & $21.30 \pm 0.017^{\mathrm{d}}$ & $43.96 \pm 1.43^{c}$ & $460.94 \pm 5.97^{d}$ \\
\hline$N$. hexagonolepis & $\begin{array}{c}6.47 \pm 1.31^{c} \\
78.99 \pm 0.39^{*}\end{array}$ & $3.20 \pm 0.012^{\mathrm{e}}$ & $93.53 \pm 1.31^{\mathrm{c}}$ & $23.81 \pm 0.020^{c}$ & $14.01 \pm 0.010^{\mathrm{e}}$ & $52.51 \pm 1.27^{\mathrm{d}}$ & $431.39 \pm 5.24^{\mathrm{e}}$ \\
\hline R. bola & $\begin{array}{c}6.79 \pm 0.57^{\mathrm{c}} \\
78.72 \pm 0.15^{*}\end{array}$ & $2.37 \pm 0.008^{\mathrm{d}}$ & $93.21 \pm 0.57^{\mathrm{c}}$ & $21.91 \pm 0.012^{\mathrm{d}}$ & $15.01 \pm 0.010^{\mathrm{b}}$ & $53.92 \pm 0.57^{\mathrm{e}}$ & $438.38 \pm 2.26^{\mathrm{f}}$ \\
\hline T. putitora & $\begin{array}{c}7.43 \pm 0.68^{\mathrm{a}} \\
73.16 \pm 0.28^{*}\end{array}$ & $2.70 \pm 0.013^{c}$ & $92.57 \pm 0.68^{\mathrm{a}}$ & $25.55 \pm 0.025^{\mathrm{e}}$ & $22.64 \pm 0.012^{f}$ & $41.68 \pm 0.64^{\mathrm{a}}$ & $472.71 \pm 2.76^{\mathrm{g}}$ \\
\hline C. semiplotum & $\begin{array}{l}6.92 \pm 0.34^{c} \\
80.56 \pm 0.4^{*}\end{array}$ & $1.54 \pm 0.033^{\mathrm{a}}$ & $93.28 \pm 0.55^{\mathrm{c}}$ & $23.13 \pm 0.094^{\mathrm{f}}$ & $29.85 \pm 0.010^{\mathrm{g}}$ & $38.55 \pm 0.21^{\mathrm{f}}$ & $521.38 \pm 9.23^{\mathrm{h}}$ \\
\hline B. barna & $\begin{array}{c}8.20 \pm 0.14^{\mathrm{d}} \\
79.93 \pm 0.53^{*}\end{array}$ & $1.28 \pm 0.017^{\mathrm{a}}$ & $91.80 \pm 0.14^{\mathrm{d}}$ & $23.12 \pm 0.012^{\mathrm{f}}$ & $13.51 \pm 0.010^{\mathrm{h}}$ & $53.89 \pm 0.14^{\mathrm{e}}$ & $429.66 \pm 0.65^{\mathrm{i}}$ \\
\hline P. nudithoracicus & $\begin{array}{c}5.44 \pm 2.20^{\mathrm{e}} \\
79.54 \pm 0.75^{*}\end{array}$ & $1.34 \pm 0.004^{\mathrm{a}}$ & $94.56 \pm 2.20^{\mathrm{e}}$ & $22.94 \pm 0.012^{\mathrm{a}}$ & $26.13 \pm 0.094^{\mathrm{i}}$ & $44.14 \pm 2.15^{c}$ & $503.52 \pm 9.06^{j}$ \\
\hline
\end{tabular}

"Moisture content of fresh sample. Data expressed as mean of 3 replicates \pm standard deviation; The values with different letters in a column are significantly different from each other at $\mathrm{p}<0.05$. 
TABLE-3

MINERAL CONTENTS OF TEN FISH SPECIES PER $100 \mathrm{~g}$ OF DRY WEIGHT

\begin{tabular}{lccccc}
\hline \multicolumn{1}{c}{ Fish species } & $\mathrm{Fe}(\mathrm{mg})$ & $\mathrm{Cu}(\mathrm{mg})$ & $\mathrm{Mg}(\mathrm{mg})$ & $\mathrm{Ca}(\mathrm{mg})$ & $\mathrm{Zn}(\mathrm{mg})$ \\
\hline B. bendelisis & $8.98 \pm 0.023^{\mathrm{a}}$ & $1.89 \pm 0.013 \mathrm{a}$ & $0.31 \pm 0.008^{\mathrm{a}}$ & $0.59 \pm 0.016^{\mathrm{a}}$ & $1.06 \pm 0.044^{\mathrm{a}}$ \\
C. chagunio & $21.89 \pm 0.029^{\mathrm{b}}$ & $1.90 \pm 0.022^{\mathrm{a}}$ & $0.22 \pm 0.012^{\mathrm{a}}$ & $0.60 \pm 0.012^{\mathrm{a}}$ & $3.32 \pm 0.030^{\mathrm{b}}$ \\
G. gotyla & $13.26 \pm 0.042^{\mathrm{c}}$ & $1.92 \pm 0.024^{\mathrm{a}}$ & $0.14 \pm 0.009^{\mathrm{a}}$ & $0.30 \pm 0.012^{\mathrm{a}}$ & $1.56 \pm 0.063^{\mathrm{a}}$ \\
L. pangusia & $17.27 \pm 0.020^{\mathrm{d}}$ & $1.50 \pm 0.014^{\mathrm{a}, \mathrm{b}}$ & $0.20 \pm 0.006^{\mathrm{a}}$ & $0.62 \pm 0.010^{\mathrm{a}}$ & $2.90 \pm 0.030^{\mathrm{c}}$ \\
N. hexagonolepis & $21.44 \pm 0.078^{\mathrm{b}}$ & $2.91 \pm 0.029^{\mathrm{c}}$ & $0.18 \pm 0.003^{\mathrm{a}}$ & $0.52 \pm 0.012^{\mathrm{a}}$ & $1.46 \pm 0.047^{\mathrm{a}}$ \\
R. bola & $13.70 \pm 0.012^{\mathrm{c}}$ & $0.523 \pm 0.034^{\mathrm{d}}$ & $0.22 \pm 0.013^{\mathrm{a}}$ & $0.44 \pm 0.012^{\mathrm{a}}$ & $4.51 \pm 0.029^{\mathrm{d}}$ \\
T. putitora & $19.98 \pm 0.086^{\mathrm{d}}$ & $1.07 \pm 0.030^{\mathrm{b}}$ & $0.24 \pm 0.007^{\mathrm{a}}$ & $0.53 \pm 0.009^{\mathrm{a}}$ & $3.57 \pm 0.055 \mathrm{~b}$ \\
C. semiplotum & $10.29 \pm 0.05^{\mathrm{e}}$ & $1.49 \pm 0.001^{\mathrm{b}}$ & $0.14 \pm 0.006^{\mathrm{a}}$ & $0.60 \pm 0.020^{\mathrm{a}}$ & $2.91 \pm 0.033^{\mathrm{c}}$ \\
B. barna & $5.56 \pm 0.071^{\mathrm{f}}$ & $1.11 \pm 0.029^{\mathrm{b}}$ & $0.31 \pm 0.017^{\mathrm{a}}$ & $0.64 \pm 0.020^{\mathrm{a}}$ & $1.90 \pm 0.029^{\mathrm{a}}$ \\
P. nudithoracicus & $7.45 \pm 0.066^{\mathrm{a}}$ & $1.42 \pm 0.044^{\mathrm{b}}$ & $0.17 \pm 0.007^{\mathrm{a}}$ & $0.59 \pm 0.020^{\mathrm{a}}$ & $1.45 \pm 0.041^{\mathrm{a}}$ \\
\hline
\end{tabular}

Data expressed as mean of 3 replicates \pm standard deviation; The values with different letters in a column are significantly different from each other at $\mathrm{p}<0.05$.

smoke-dried hill stream fishes from Manipur, India that ranged from $1.7105 \pm 0.36$ to $8.375 \pm 0.03 \mathrm{mg} / 100 \mathrm{~g}$. While the iron content of some local fishes of Tripura, India reported by Debnath et al. [16] was found varying from $9.18 \mathrm{mg}$ to 99.77 $\mathrm{mg}$ per $100 \mathrm{~g}$ which is higher in comparison to that of this investigation. The recommended daily intake of iron is $8 \mathrm{mg}$ and $18 \mathrm{mg}$ for adult male and female, respectively [12]. The highest amount of copper was observed in $N$. hexagonolepis $(2.91 \pm 0.029 \mathrm{mg})$ and the lowest in $R$. bola $(0.523 \pm 0.034$ $\mathrm{mg})$. Copper plays an important role in biological electron transport and is essential for enzyme production in the body [12]. Its deficiency causes reduced energy production, abnormal glucose and cholesterol metabolism, and increased oxidative damage [12]. The levels of magnesium ranged from $0.14 \pm 0.006 \mathrm{mg}$ in $C$. semiplotum to $0.31 \pm 0.017 \mathrm{mg}$ in $B$. barna and calcium varied from $0.30 \pm 0.012 \mathrm{mg}$ ( G. gotyla) to $0.64 \pm 0.020 \mathrm{mg}$ (B. barna). The amount of zinc was found to be highest in $R$. bola $(4.51 \pm 0.029 \mathrm{mg})$ and the lowest in $B$. bendelisis $(1.06 \pm 0.044 \mathrm{mg})$. The level of zinc in this study was found almost similar to that of some fish species of Bangladesh reported by Bogard et al. [27]. Hei and Sarojnalini [17] also reported the zinc content of some smoke-dried hill stream fishes from Manipur, India that ranged from $0.4375 \pm$ $0.00 \mathrm{mg} / 100 \mathrm{~g}$ to $3.750 \pm 0.00 \mathrm{mg} / 100 \mathrm{~g}$.

\section{Conclusion}

This study provides information about nutritional composition of the ten fish species from Hel river of North-East India. The investigation showed that these fish species could be good sources of proteins, fats, minerals and high nutritive value. Hence, these can be suggested as an alternative source of protein, fat, and high nutritive value and can aid as a healthy addition in the human diet.

\section{ACKNOWLEDGEMENTS}

The authors are thankful to Zoological Survey of India, Shillong (Meghalaya) for identification of fishes, SAIF, North Eastern Hill University, Shillong, India, for mineral analysis and Department of Food Engineering and Technology, Central Institute of Technology, Kokrajhar, India for providing facilities for protein estimation.

\section{REFERENCES}

1. M. Begum, T. Akter and M.H. Minar, Environ. Sci. Nat. Resour., 5, 69 (2012).
2. D. Sarma, M.S. Akhtar, P. Das, P. Das, G. Gadiya, N. Shahi and A. Ciji, Nutr. Food Sci., 44, 554 (2014); https://doi.org/10.1108/NFS-08-2013-0096.

3. M.A. Ogundiran, S.O. Adewoye, T.A. Ayandiran and S.O. Dahunsi, Afr. J. Biotechnol., 13, 1147 (2014); https://doi.org/10.5897/AJB2013.13240.

4. D. Sarma, M.S. Akhtar, P. Das, P. Das, N. Shahi, A. Ciji, P.C. Mahanta, S. Yengkokpam and D. Debnath, Natl. Acad. Sci. Lett., 36, 385 (2013); https://doi.org/10.1007/s40009-013-0151-1.

5. S.M.D. Alam, M.H. Karim, A. Chakrabortty, R. Amin and S. Hasan, Int. J. Food Sci. Nutr. Eng., 6, 1 (2016).

6. A.P. Simopoulos, Biomed. Pharmacother, 56, 365 (2002); https://doi.org/10.1016/S0753-3322(02)00253-6.

7. K.V. Dhaneesh, K.M. Noushad and T.T. Ajith Kumar, PLoS One, 7, e45439 (2012); https://doi.org/10.1371/journal.pone.0045439.

8. C.N. Glover and C. Hogstrand, J. Exp. Biol., 205, 151 (2002).

9. H.A.E. Mohamed, R. Al-Maqbaly and H.M. Mansour, Afr. J. Food Sci., 4, 650 (2010)

10. G.S. Ojewola and S.I. Annah, Int. J. Poult. Sci., 5, 390 (2006); https://doi.org/10.3923/ijps.2006.390.394

11. S. Sutharshin and K. Sivashanth, Int. J. Biol. Chem., 6, 161 (2011); https://doi.org/10.3923/ijbc.2011.161.169.

12. A. Islary, J. Sarmah and S. Basumatary, J. Invest. Biochem., 5, 21 (2016); https://doi.org/10.5455/jib.20160422015354.

13. A. Islary, J. Sarmah and S. Basumatary, Med. J. Nutr. Metab., 10, 29 (2017); https://doi.org/10.3233/MNM-16119.

14. H. Narzary, A. Islary and S. Basumatary, Med. J. Nutr. Metab., 9, 191 (2017); https://doi.org/10.3233/MNM-16116.

15. A. Islary, J. Sarmah and S. Basumatary, J. Pharm. Nutr. Sci., 7, 55 (2017); https://doi.org/10.6000/1927-5951.2017.07.02.4.

16. C. Debnath, L. Sahoo, A. Singha, G.S. Yadav, M. Datta and S.V. Ngachan, Indian J. Hill Farming, 27, 120 (2014).

17. A. Hei and C. Sarojnalini, Nat. Sci., 10, 59 (2012).

18. W.S. Devi and C. Sarojnalini, Int. J. Sci. Res., 2, 257 (2013).

19. N. Ullah, P. Hazarika and P.J. Handique, Int. Adv. Res. J. Sci. Eng. Technol., 3, 30 (2016); https://doi.org/10.17148/IARJSET.2016.3107

20. H. Romharsha, A.H. Abdul Hei and C.S. Ch. Sarojnalini, Int. J. Scient. Res., 3, 170 (2014); https://doi.org/10.15373/22778179/August2014/49.

21. AOAC, Official Methods of Analysis, Association of Official Analytical Chemists, Virginia, USA, edn 17 (2000).

22. C.S. James, Analytical Chemistry of Foods, Chapman and Hall, New York, edn 1 (1995).

23. FAO Food Energy-Methods of Analysis and Conversion Factors, FAO Food and Nutrition Paper 77 (2003).

24. K.I. Jeyasanta and J. Patterson, World J. Fish Marine Sci., 6, 275 (2014).

25. F. Jabeen and A.S. Chaudhry, Food Chem., 125, 991 (2011); https://doi.org/10.1016/j.foodchem.2010.09.103.

26. H. Narzary, A. Swargiary and S. Basumatary, J. Mol. Pathophysiol., 4, 128 (2015); https://doi.org/10.5455/imp.20151111030040.

27. J.R. Bogard, S.H. Thilsted, G.C. Marks, M.A. Wahab, M.A.R. Hossain, J. Jakobsen and J. Stangoulis, J. Food Compos. Anal., 42, 120 (2015); https://doi.org/10.1016/i.jfca.2015.03.002. 